\title{
ARTICLES
}

\section{Patents, Meet Napster: 3D Printing and the Digitization of Things}

\author{
Deven R. Desai* \& Gerard N. Magliocca**
}

Digitization has reached things. This shift promises to alter the business and legal landscape for a range of industries. Digitization has already disrupted copyright-based industries and laws. As cost barriers fell, individuals engaged with copyrighted work as never before. Business-to-business and business-toconsumer models of industrial copyright faltered and, in some cases, failed. Industries were forced to reorganize, and the foundations of copyright were reexamined. This Article assesses a prime example of the next phase of digitization: $3 D$ printing and its implications for intellectual property law and practice.

$3 D$ printing is a general-purpose technology that will do for physical objects what MP3 files did for music. The core patent bargain-sharing how to make something in exchange for exclusivity-may be meaningless in a world of digitized things. While $3 D$ printers will unleash the creativity of producers and reduce costs for consumers, they will also make it far easier to infringe patents, copyrights, and trade dress. This will compel firms to rethink their business practices and courts to reconsider not only patent law but also long-established doctrine in areas ranging from copyright merger to trademark post-sale confusion. Moreover, Congress will need to consider establishing some sort of infringement exemption for $3 D$ printing in the home and expanding the noticeand-takedown rules of the Digital Millennium Copyright Act to websites that host software enabling 3D printing of patented items and distinctive trade dress. While a $3 D$ printer is not yet a common household item, the time to start thinking about that future is now.

\footnotetext{
* Associate Professor of Law and Ethics, Georgia Institute of Technology, Scheller College of Business.

** Samuel R. Rosen Professor, Indiana University Robert H. McKinney School of Law. (C) 2014, Deven R. Desai and Gerard N. Magliocca. Professor Desai was an associate professor of law at Thomas Jefferson School of Law when this Article began and thanks the School for its support. In addition, the authors would like to thank William Byrd and Mark French for explaining the physics of 3D printing and Katie Rast for her guidance about the way 3D printers and the Maker movement are changing manufacturing practices. We also thank Lydia Loren for her insights and feedback. The work has benefitted from attendees' comments at the Lewis and Clark Faculty Colloquium, Microsoft Research Center, Cambridge's speaker series, Stanford Law School's Design Patents in the Modern World conference, Works in Progress IP at Seton Hall, and American Law Institute's Young Scholars Medal Conference on Copyright and Patent Law. Finally, we are grateful to the organizers of this Symposium for inviting us to present our work.
} 


\section{TABLE OF CONTENTS}

INTRODUCTION

I. Personal Factories $\ldots \ldots \ldots \ldots \ldots$. . . . . . . . . . . . 1695

A. THE PC AS FACTORY: THE MECHANICS OF 3D PRINTING . . . . . 1695

B. 3D PRINTING AND THE ECONOMY . . . . . . . . . . . . . . . . . 1697

C. PREDICTING AND PROTECTING THE FUTURE: GUNS AND OTHER RED

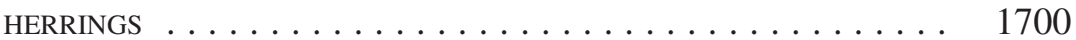

II. Patent, Copyright, and Trademark . . . . . . . . . . . . . . 1703

A. PATENTS: INFORMATION EXCHANGE AND CHANGING

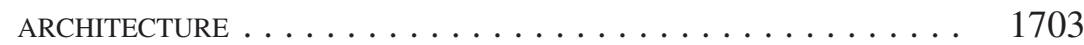

B. COPYRIGHT ORIGINALITY AND MERGER . . . . . . . . . . 1705

C. TRADE DRESS AND BRANDING . . . . . . . . . . . . . . . . . . . 1709

III. Congressional Regulation . . . . . . . . . . . . . . . . . . 1713

A. THE 3D ECOSYSTEM . . . . . . . . . . . . . . . . . 1714

B. LIFTING THE THREAT OF PERSONAL INFRINGEMENT LIABILITY . . . 1716

C. A PATENT AND TRADEMARK DMCA . . . . . . . . . . . . . 1718

ConcLusion . . . . . . . . . . . . . . . . . . . . . . . . . . . . . 1719

\section{INTRODUCTION}

We live in a world of digitized things. Digitization changes any sector it touches. At first, skill and monetary costs limit the effect of those changes. But when the changes scale-in other words, when the costs drop and a wide range of businesses and people can use the power of digitization-business and legal realities shift dramatically. Disruption is not only a business or private matter; the underlying legal system is disrupted as well. 3D (or additive) printing brings the promise and challenge of digitization to tangible goods. Many copyright and trademark-based industries have faced digitization, but patent-based industries have not. Advances in 3D printing technology are launching an Industrial Counter-Revolution, ${ }^{1}$ and the laws governing the way things are made will need to make peace with the reality of digitized objects and on-demand fabrication.

1. There are desktop devices_-milling machines - that use subtraction to make objects and raise many of the same legal issues created by 3D printers. See Tom Owad, When Less Is More: The Takeaway on Milling vs. 3D Fabrication, MAKE:, Winter 2013, at 10, 11. We do not address milling devices in this Article. 
The promise of 3D printing is that people will be free to make almost anything they want themselves, which opens the door to a new wave of innovation from the home, the start-up, and large firms. If your daughter likes toys with features that you cannot find at the store, then you can make them yourself. If your customers want goods suited to their individual quirky tastes, then you can easily match their preferences. ${ }^{2}$ And if standardized parts cannot meet market demand, then you can cost-effectively produce many varieties. The easy ability to customize virtually anything also opens doors for the disabled, the elderly, or anyone who finds that their particular needs are not being met or are unaffordable. Some may question whether consumers will want to embrace these options. Yet Starbucks now faces competition from Keurig, and CocaCola from SodaStream, because technology has brought mass-production techniques for espresso- and soda-making into the home. $3 \mathrm{D}$ printing promises to further that trend.

Patent law relies, in part, on the premise that the cost to infringe is relatively high, but 3D printing challenges that assumption. ${ }^{3}$ The Industrial Revolution and the parallel growth of intellectual property laws supporting that economy were driven by economies of scale. ${ }^{4}$ Plenty of capital was necessary to support research, production, and distribution, and therefore any serious infringement also required a substantial investment. That nineteenth-century model is crumbling. ${ }^{5}$ Copyright was the canary in the coalmine. ${ }^{6}$ Once music, film, and books were digitized, those industries were transformed. Production costs fell. Distribution became fast, cheap, and on-demand. Many new players entered the market. Patent is starting down that same road. In short, digitization has reached the rest

2. See Hod Lipson \& Melba Kurman, Fabricated: The New World of 3D Printing 46-47, 59 (2013) (describing "cloud manufacturing" and customized, on-demand manufacturing).

3. See Daniel Harris Brean, Asserting Patents to Combat Infringement via 3D Printing: It's No "Use”, 23 Fordham Intell. Prop. Media \& Ent. L.J. 771, 781-82 (2013); Davis Doherty, Note, Downloading Infringement: Patent Law as a Roadblock to the 3D Printing Revolution, 26 HaRv. J.L. \& ТЕСн. 353, 354 (2012).

4. See, e.g., H.I. Dutton, The Patent System and Inventive Activity During the Industrial Revolution 1750-1852, at 103-49 (1984); accord Robert P. Merges et Al., Intellectual Property in the New Technological Age 125 (6th ed. 2012). For a view of how changes in the economy from pre-industrial real property to industrial-era corporate property shaped the structure of copyright law and how today's information-age economy should affect and shape copyright policy, see generally Julie E. Cohen, Copyright as Property in the Post-Industrial Economy: A Research Agenda, 2011 Wis. L. ReV. 141.

5. Cf. LiPSON \& KuRMan, supra note 2, at 45-47 (arguing that distributed "cloud manufacturing" will displace the current centralized mass manufacturing just as has happened in data and financial sectors).

6. See Metro-Goldwyn-Mayer Studios, Inc. v. Grokster, Ltd., 545 U.S. 913, 919 (2005) (rejecting a claim for contributory copyright infringement based on the online sharing of MP3 files); see also Doherty, supra note 3, at 354 ("3D printing also enables widespread patent infringement in the form of digital downloads in much the same manner that the advent of digital music enabled widespread copyright infringement."). See generally Raymond Shih Ray Ku, The Creative Destruction of Copyright: Napster and the New Economics of Digital Technology, 69 U. CHI. L. REv. 263 (2002) (giving a prescient overview of the shift in music distribution). 
of the economy - the economy of things. ${ }^{7}$

This Article explores how 3D printing will disrupt patents and other forms of intellectual property that have relied on physical limits to prevent infringement. Current doctrine recognizes the slim chance that an individual or a small business will have the wherewithal to make an infringing item from scratch, but 3D printers will make that much easier. This shift will reduce the value of many patents, some copyrights, and all trade dress, because even the best efforts to stop this surge in infringement will fall short. 3D printing should also accelerate the pace at which design, prototyping, and entrepreneurial launches and failures occur. Thus, these devices offer specific opportunities for creation and the benefits of many other general-purpose technologies: rapid, unpredictable experimentation; faster learning; and increased knowledge growth. As one author has said, "Radically new technology inspires lyrical utopianism and melancholy catastrophism."

Whether 3D printing will realize all the dreams it currently inspires is not the question. Predicting a given technology's outcome has never been precise or accurate. The benefits and costs of Edison's light bulb, nuclear reactors, the use of Freon as a coolant, and other technologies were and are unpredictable. ${ }^{9}$ Society must always adapt to or "diffuse" technology's unforeseen outcomes. ${ }^{10}$ Solutions to initial unforeseen problems often prompt another cycle of hidden costs and benefits. ${ }^{11}$ Exactly how 3D printing will take hold in society is not set, but its rapid uptake at different layers of society indicates disruption of some sort is at hand and growing. We do not need to know how 3D printing will take hold to know that incumbents will challenge the technology. ${ }^{12}$ Part of that strategy will be to demand that the law limit the technology. In short, the law plays a role in any technology's possibility of success and will do so for 3D printing. As such, we argue the full potential of these personal factories will not be realized unless Congress establishes a sensible regulatory regime that: (1) removes the shadow of infringement liability from some people who use 3D printers for personal purposes; and (2) provides clear rules for websites that host

7. Cf. Michael J. Madison, Law as Design: Objects, Concepts, and Digital Things, 56 CASE W. Res. L. REv. 381, 477-78 (2005) ("The question for things is a broader form of the narrow question raised by copyright and patent: what is the role of the law in preserving and shaping the forms that our 'creative' institutions produce?").

8. Edward Tenner, Nanotechnology and Unintended Consequences, in SocIETAL IMPLICATIONS of Nanoscience and Nanotechnology 311, 311 (Mihail C. Roco \& William Sims Bainbridge eds., 2001).

9. See id. at 312-13.

10. Id.

11. Id.

12. As science and technology studies have offered, engineering is social. "Both humans and non-humans have interests that need to be accommodated, and that can be managed and used." SERGIO Sismondo, An Introduction to Science And Technology Studies 65 (2004). Purveyors of new technology must look beyond the "obvious boundaries of engineered artifacts" and present a vision of how the new technology fits into society. Id. The electric car is but one example of a technology that works but has faced continual "critici[sm] [of] both the technical details and the social feasibility" of them. Id. 
the programs that let these devices function. ${ }^{13}$ At the same time, companies with a vested interest in the current system must not be allowed to use concerns about homemade guns or other distractions as an excuse to shackle 3D printing. ${ }^{14}$

Part I of this Article explains how 3D printers work and looks at their broader economic and social implications. Part II considers the patent, copyright, and trademark issues raised by these devices. Part III looks at some of the 3D printing questions that Congress will face in the coming years.

\section{Personal Factories}

$3 \mathrm{D}$ printing reorders access to the means of production. Thinking about 3D printers as just another peripheral device for a computer or a tablet is a mistake. 3D printers are a general-purpose technology for design and production. Virginia Woolf said, "[O]n or about ... 1910 human character changed." 15 Some have argued that claim was correct because of a cultural shift from "a productionoriented society of small entrepreneurs" to "a consumption-oriented society dominated by ... corporations. ${ }^{~} 16$ $3 \mathrm{D}$ printing promises a shift that can reinvigorate production by small entrepreneurs. These devices are part of a broader "maker movement" that seeks to empower people to create customized goods in their home or business. This Part explains the fundamentals of 3D printing and outlines its potential. ${ }^{17}$

\section{A. THE PC AS FACTORY: THE MECHANICS OF 3D PRINTING}

3D printers are modeled on a familiar item-the desktop printer-and operate along similar lines. ${ }^{18}$ They employ an additive process, which involves squirting molten plastic, targeting a laser to harden layers of powder or liquid resin, or shaping other materials such as metal, cake frosting, or living cells, to make an object. ${ }^{19}$ The raw material is set into two-dimensional patterns on a platform that is gradually raised to let each layer stack on top of the next until

13. See Doherty, supra note 3, at 365-69 (calling for the enactment of a Digital Millennium Patent Act).

14. See, e.g., Peter Jensen-Haxel, Comment, 3D Printers, Obsolete Firearm Supply Controls, and the Right to Build Self-Defense Weapons Under Heller, 42 Golden Gate U. L. Rev. 447, 447-49 (2012).

15. Virginia Woolf, Mr. Bennet and Mrs. Brown 4 (1924); accord Jerre B. Swann, Sr., Dilution Redefined for the Year 2002, 92 TRADEMARK REP. 585, 587 (2002).

16. Swann, supra note 15, at 587 (quoting T. J. Jackson Lears, From Salvation to Self-Realization: Advertising and the Therapeutic Roots of the Consumer Culture, 1880-1930, in The Culture of Consumption: Critical Essays in American History, 1880-1980, at 1, 3 (Richard Wightman Fox \& T. J. Jackson Lears eds., 1983)).

17. There are many exotic possibilities for 3D printing (for example, making entire human organs for transplants), but we choose to focus on the applications that are more realistic in the short- or medium-term.

18. See Chris Anderson, Makers: The New Industrial Revolution 90-92 (2012).

19. See id. at 83; see also Bill Bumgarner, Getting Started with a 3D Printer, MAKE:, Winter 2013, at 12, 12 ("There are three approaches to additive manufacturing in common use: photopolymerization (using light to cure a liquid material into solids of the desired shape), granular materials binding (using lasers, hot air, or other energy sources to fuse layers of powder into the desired shape), and the focus of 
the item is complete. These patterns and adjustments are controlled by computeraided design (CAD) files, which are often open source and can be downloaded for free on websites such as Thingiverse.com. ${ }^{20}$ Producing a design from scratch, however, is not hard. 3D modeling programs allow people to draw what they want and are being used in middle and high schools. But design programs are not always required. 3D scanners, such as MakerBot's Digitizer Desktop 3D Scanner, bring science fiction to life by using lasers and cameras to allow anyone to capture the contours of an object and turn them into a CAD. ${ }^{21}$ Other software lets people upload photos of something from different angles and convert the images into a CAD. ${ }^{22}$ And in the not-too-distant future, your cell phone will be able to scan objects and produce 3D printer files. ${ }^{23}$

The 3D printing business resembles the early PC industry. ${ }^{24}$ Today, the printers are built mainly for hobbyists and researchers, not for consumers. They are finicky and often do not work. They look like a box without side panels, a true open architecture that is perfect for those who like tinkering. An ordinary household would find most of the current models inconvenient. But almost every revolutionary product has growing pains. Garage inventors, hobbyists, and tinkerers meet, share ideas, start companies, fail, start again, fail, consolidate, and so on until over time the technology gets better, cheaper, and consumer grade. There is no reason to think 3D printers will not do the same. Indeed, just as Kinko's set up computers and printers for rent, UPS has started deploying 3D printers for people to come in and use at its stores. Staples now sells a desktop 3D printer for around $\$ 1300$ alongside its PC, notebook, and standard printer offerings. And design firm, Autodesk, offers its open-source software platform, Spark, to make both 3D printer operating systems and design software even "easier to control." ${ }^{25}$ In short, the hardware, software, and material science necessary for 3D printing continue to improve rapidly and allow for more sophisticated, easy-to-use, and less expensive 3D printing at all levels of industry. Depending on your point of view, this new reality is either scary or thrilling.

this article, molten polymer deposition (MPD; extruding molten material in layers to build up the desired shape).").

20. See, e.g., Brian Rideout, Printing the Impossible Triangle: The Copyright Implications of Three-Dimensional Printing, 5 J. Bus. Entrepreneurship \& L. 161, 163-64 (2011).

21. See Anderson, supra note 18, at 84; Sean Buckley, MakerBot's Digitizer Will Go on Sale Next Week, Promises 3D Scanning to the Masses, Engadget (Aug. 14, 2013, 7:05 PM), http://www.engadget. com/2013/08/14/makerbots-digitizer-will-go-on-sale-next-week.

22. See Anna Kaziunas France, Skill Builder: 3D Scanning, MAKE:, Winter 2013, at 92, 92.

23. See ANDERSON, supra note 18, at 98.

24. For example, certain raw materials can be melted only at a temperature that is higher than what a desktop machine can safely reach. Other materials, especially metal, are brittle when heated and thus need more careful handling than current 3D printers can provide. Finally, many items are too complex or too large to print with current technology.

25. See Scott Dunham, Autodesk's Spark: Android of 3D Printing?, InformationWeek (May 22, 2014, 9:06 AM), http://www.informationweek.com/strategic-cio/executive-insights-and-innovation/ autodesks-spark-android-of-3d-printing/a/d-id/1269107. 


\section{B. 3D PRINTING AND THE ECONOMY}

3D printing will unleash the power of digitized things on manufacturers. The PC and the Internet put digitization into consumers' hands, slashed copying and distribution costs, and weakened entry barriers to economic sectors that provided certain nonrivalrous goods. Nonrivalrous goods are like an idea; once created, their capacity is infinite as "there is no additional marginal cost in allowing others to use [them]." 26 The reproduction of an idea does not consume it. We can all use it simultaneously. Utilitarian justifications for intellectual property protection assert that the law must provide protection for nonrivalrous goods $^{27}$ because of this ease of copying. Once digitization hit the copyright industry, it felt the full force of nonrivalry. Instead of industrial competitors having cost barriers provide an advantage similar to rivalry, almost anyone could make and distribute copyrighted goods. To date, companies relying on patent to protect nonrivalrous goods have not had to face potential broad-based copying. 3D printing will challenge those companies. Lower costs, the ability to make specialized and just-in-time parts, and a return to local manufacturing are all positive developments that should be embraced. ${ }^{28}$ Yet these advances will threaten, if not destroy, many firms and jobs that live off rents from intellectual property.

Champions of 3D printing invoke its potential for innovation, ${ }^{29}$ but what does that mean? The best explanation is that $3 \mathrm{D}$ printing affects three levels of

26. Deven R. Desai, The Life and Death of Copyright, 2011 WIS. L. REv. 219, 255; see also Brett M. Frischmann, An Economic Theory of Infrastructure and Commons Management, 89 MinN. L. REv. 917 , 946 (2005) ("An idea only needs to be created once to satisfy consumer demand while an apple must be produced for each consumer. Essentially, this means that the marginal costs of allowing an additional person to use an idea are zero.").

27. Frischmann, supra note 26, at 949 n.114 (noting William Landes and Richard Posner's work on copyright theory and their explanation that unlike tangible goods, intellectual goods are easily copied at little or almost no cost after creation). But see Brett M. Frischmann \& Mark A. Lemley, Spillovers, 107 Colum. L. Rev. 257, 272-73 (2007) (explaining that nonrivalrous goods allow for simultaneous use without depriving others of use and that often such use is a spillover use which does not compensate the creator but often produces another creation which others may use rather than being a passive consumer).

28. $C f$. Eric von Hippel, Democratizing Innovation 1 (2005) ("When I say that innovation is being democratized, I mean that users of products and services-both firms and individual consumers-are increasingly able to innovate for themselves. User-centered innovation processes offer great advantages over the manufacturer-centric innovation development systems that have been the mainstay of commerce for hundreds of years. Users that innovate can develop exactly what they want, rather than relying on manufacturers to act as their (often very imperfect) agents. Moreover, individual users do not have to develop everything they need on their own: they can benefit from innovations developed and freely shared by others."); Eric von Hippel et al., Comparing Business and Household Sector Innovation in Consumer Products: Findings from a Representative Study in the UK (Nov. 2011) (unpublished manuscript), available at http://ssrn.com/abstract=1683503 (measuring consumer modification and innovation of producer goods and finding significant innovation benefits that could benefit existing companies).

29. 3D printing is seen as important enough that the Obama administration created the National Additive Manufacturing Innovation Institute (NAMII) to support the field. See Bumgarner, supra note 19 , at 12 . 
manufacturing: the home, the start-up, and the assembly line. In the home, 3D printing provides the chance to make items that are not mass-produced. Neil Gershenfeld of MIT calls this personal fabrication "to make what you can't buy at Wal-Mart." ${ }^{30}$ For example, the toy or auto industry may find that their products become a platform. Today, if you buy a doll, a Lego set, or a car, the ability to alter, tinker, or improve your purchase is low. 3D printing, however, opens the door to personal improvement. You still buy the doll or dollhouse; but once a child is bored, 3D printing allows you to design and create new heads, limbs, or furniture. Instead of relying on Lego to decide what a piece looks like or does, the consumer can make new ones. ${ }^{31}$ Car enthusiasts can make old parts no longer in production or new custom parts. Given the human tendency to share designs and the fact that not everyone will want a 3D printer, these creators may end up selling their adaptations directly to customers. The world of commissioned 3D objects would thus expand the model of Etsy, which has become a marketplace connecting those who offer handmade and customized crafts to consumers. The artisanal part of the economy would grow. ${ }^{32}$

Skeptics might rightly ask why we think that many individuals would want to make things at home that are inexpensive and readily available in stores. To answer that question, consider the market for homemade soda. Soda may be the most ubiquitous consumer good in the United States, yet there is a growing market for simple devices that carbonate water and let people add their own flavoring to make a beverage. ${ }^{33}$ Why is that? One answer is that it reduces the number of cans and bottles a family must consume, which appeals to those who are environmentally conscious. Another possibility is that it saves soda guzzlers money. Most important, though, is that people have different soda preferences. Some like more fizz; some like less. Some want more flavoring, less flavoring, or a mix of flavorings. Soda manufacturers such as Coca-Cola cannot meet these variations in demand - there are too many. And now with the ease of a general-purpose soda machine, what was once a nuisance or impractical to do at home is a cost-saving and customized option. The same is true for many other consumer products, and 3D printing can unlock that demand. ${ }^{34}$

Meanwhile, start-ups can use 3D printers to compete effectively with industrial giants. Once economies of scale no longer provide a substantial edge, small companies can succeed in industries that were traditionally dominated by big business. For example, Local Motors-based in Arizona-is using this ap-

30. Anderson, supra note 18 , at 77.

31. See id. at 62-63; NeIl Gershenfeld, Fab: The Coming Revolution on Your Desktop-From Personal Computers to Personal Fabrication 41 (2005) (noting possibility of "mass customization").

32. Cf. Gershenfeld, supra note 31 , at 8 (arguing a return to local, custom manufacture of goods is a return to "industrial roots" and artisanship).

33. SodaStream is the most common brand in this area, and owners of that machine just need to refill the gas canister from time to time.

34. The easy availability of customized products will also shape preferences and make more people demand these types of goods. We thank Rebecca Tushnet for making this observation at the Symposium. 
proach to launch a specialized auto business. The business relies, in part, on crowd-sourced parts from the Maker community. As opposed to the massproduction system of other companies, it is easy to design and test parts using 3D printers and then create the parts as needed. ${ }^{35}$ Insofar as 3D printers are part of flexible manufacturing, Tesla's approach to making electric cars is a broader example of how technology to make specialized items-but not invest in large, single-purpose assembly lines-sparks innovation and new businesses. ${ }^{36}$

Larger firms can also benefit from 3D printers. These devices can costeffectively do a lot of work now done by lower skill workers overseas, which means that some production can move back to the United States and Europe. ${ }^{37}$ Bringing manufacturing closer to the market allows firms to hold lower inventories, reduce shipping and environmental costs, and avoid other risks that are endemic to work done offshore. ${ }^{38}$ For example, GE Aviation recently purchased Morris Technologies, a precision engineering firm that relies on 3D printing, because the process generates less waste, allows for rapid prototyping of parts, and uses materials that are well suited for the production of jet engines. ${ }^{39}$ In short, 3D printing will result in faster speed to market, lower risk because a company can test something without resorting to full-scale production, and an improved ability to make items "too intricate to be machined." 40

The cycle of faster design, prototyping, production, market launch, failure,

35. See AnDERSON, supra note 18, at 143-51.

36. Id. at $136-41$.

37. See, e.g., Comparative Advantage: The Boomerang Effect, The Economist, Apr. 21, 2012, http://www.economist.com/node/21552898. Although 3D printing will reduce the manufacturing edge enjoyed by some developing countries, in other ways the new production model will help them. Consider a Fab Lab, which is a "collection of commercially available machines and parts linked by software and processes ... developed for making things." Gershenfeld, supra note 31, at 12. The Fab Lab project deploys fabrication labs to see "which tools and processes would be most useful in the field," in developing countries like India and Ghana, remote regions such as the Lyngen Alps of northern Norway, and in inner cities. Id. at 13. These modules rely on open-source software and 3D printers that allow local workers to experiment with designs and materials that meet their needs.

38. See, e.g., Comparative Advantage, supra note 37 (noting reasons an American company moved production back to the U.S. and GE's Colorado solar production facility's ability to compete with Chinese solar panel production because of automation advances); cf. Factories and Jobs: Back to Making Stuff, The Economist, Apr. 21, 2012, http://www.economist.com/node/21552899 (describing how pharmaceutical companies are pursuing new manufacturing models that allow for local "smaller, regionalised plants" that "could respond more rapidly to local demand, especially if a pandemic were to break out," and "will fit into a shipping container, so it could be deployed anywhere").

39. See Additive Manufacturing: Print Me a Jet Engine, The Economist (Nov. 22, 2012, 12:54 PM), http://www.economist.com/blogs/schumpeter/2012/11/additive-manufacturing; $c f$. GERSHENFELD, supra note 31, at 44 (noting that "ease of use" and "design jumbo jet" were not usually "compatible concepts").

40. Collaborative Manufacturing: All Together Now, THE Economist, Apr. 21, 2012, http:// www.economist.com/node/21552902; see also Additive Manufacturing, supra note 39 ("Some people think additive manufacturing will overturn many of the economics of production because it pays no heed to unit labour costs or traditional economies of scale. Designs can be quickly changed, so the technology enables flexible production and mass customisation."). 
learn, and start over is vital to technology-driven economies. ${ }^{41} 3 \mathrm{D}$ printing enhances this cycle. Whether a given start-up or large firm succeeds does not matter. Some small makers will have solid businesses; others will go belly up. Tesla could go the way of DeLorean Motors, AOL, or InfoSeek. GE may abandon jet engines, if the margins drop. Regardless of how these industries shake out, 3D printing allows them to evolve. The rate at which they evolve will turn in part on whether 3D printing is saddled with restrictive laws that dictate how the technology can be used or is allowed to function as a general-purpose technology. Demand for specific 3D printed outputs will also play a role in whatever balance is struck.

\section{PREDICTING AND PROTECTING THE FUTURE: GUNS AND OTHER RED HERRINGS}

Every powerful technology has its drawbacks, and not everything enabled by 3D printing will be desirable. ${ }^{42}$ The task is to identify whether the resulting harms are substantial and can be addressed without restricting the technology. ${ }^{43}$ $3 \mathrm{D}$ printing continues to expand the types of materials, including metal alloys and chemicals, and complexity of things that can be made with the technology. ${ }^{44}$ The ability to print prescription drugs, illicit drugs, drug paraphernalia, sex toys, and guns suggests a dark side to $3 \mathrm{D}$ printing. ${ }^{45}$ The danger is that these potential negatives will swamp the debate so that an incumbent or one sector gains an upper hand in demanding the hammer of the law stop certain technology. Nanotechnology, which is based on the "ability to measure, manipulate and organize matter on the nanoscale-1 to 100 billionths of a meter," helps

41. Cf. AnnaLee Saxenian, The Origins and Dynamics of Production Networks in Silicon Valley, 20 Res. Pol'y 423, 424 (1991) ("The case of the computer systems business in Silicon Valley demonstrates how inter-firm networks spread the costs and risks of developing new technologies and foster reciprocal innovation among specialist firms.").

42. Cf. Douglas J. Sylvester, Kenneth W. Abbott \& Gary E. Marchant, Not Again! Public Perception, Regulation, and Nanotechnology, 3 REG. \& GoverNANCE 165, 165 (2009) ("Nanotechnology might be a platform technology ... but its effects will be determined by specific applications: some might be dangerous, some highly beneficial, and many simply useless.").

43. This is true with almost any new, powerful technology. From the Actor-Network Theory (ANT) view, both the human creators and the created technology are political. The network of people and compatible technologies operate together to increase or maintain their power. Thus the electric car may have been a great technology, but it and its creators faced social and political networks opposed to it. Nonetheless there is the possibility that the "interests [can] be accommodated, ... managed and used." See Sismondo, supra note 12, at 65.

44. See Lipson \& Kurman, supra note 2, at 83-84, 220-22.

45. See, e.g., Tim Adams, The "Chemputer" that Could Print Out Any Drug, The Observer (July 21, 2012, 17:00 EDT), http://www.theguardian.com/science/2012/jul/21/chemputer-that-prints-out-drugs (discussing 3D printing of pharmaceuticals or other inorganic drugs); Brian Anderson, 3D Printing Is Getting Stoned, Motherbodrd (Mar. 4, 2013), http://motherboard.vice.com/blog/3d-printing-is-gettingstoned (discussing drug paraphernalia); Chris Gayomali, Can You 3D Print Drugs?, The Week (June 26, 2013), http://theweek.com/article/index/246091/can-you-3d-print-drugs (noting 3D printing technology may enable ability to design and print "controlled substances" at home); David Worthington, $3 D$ Printing Is Innovating Adult Toy Industry, SmartPlanet (Feb. 21, 2013), http://www. smartplanet.com/blog/bulletin/3d-printing-is-innovating-adult-toy-industry/13437 (discussing sex toys). 
illustrate the problem. ${ }^{46}$ The debate over nanotechnology at the start of the century ranged from utopian visions of "agricultural bounty, a paradise of health and longevity, mental and physical enhancement, and a wonderland of novel consumer goods" to fears over "rampant synthetic organisms" and "quasihuman robotic systems" that could "enslave" humans. ${ }^{47}$ The true consequences of nanotechnology, however, cannot be known for a long time and may never be known. ${ }^{48}$ More generally, seemingly inconsequential changes and experimentation can lead to vast unexpected and unintended outcomes. For example, improved sewing thread led to a jump in the standard of living, and the magnetic tape vital to computers grew out of research on how to bind gold particles to cigarettes. ${ }^{49}$ In 3D printing, the possibility of making homemade guns presents a good way to explore the tension between risks and desired yet unexpected outcomes.

Making homemade guns has always been possible, but it took unusual skill, time, and equipment. Not anymore. ${ }^{50}$ In fairness, printing an entire, functioning gun in one run by a $3 \mathrm{D}$ printer is closer to fantasy than reality. ${ }^{51}$ Advances in material science and in 3D printers that render objects in metal, though, will solve this problem sooner than many may think. ${ }^{52}$ It may take longer to make a gun in one print run, but the ability to print suitable parts has already moved from short-term experimental to production quality quickly. For example, a group printed a key regulated part of an AR-15-the "lower," which is the part of the gun that has operating parts such as the trigger. ${ }^{53}$ The first iterations of

46. Tenner, supra note 8 , at 1 . Synthetic biology is another technology area that poses similar, radical drops in cost and increased numbers of people who can use the technology for good or ill. See, e.g., Andrew W. Torrance, Synthesizing Law for Synthetic Biology, 11 MinN. J.L. ScI. \& Tech. 629, 661-62 (2010) (explaining the open innovation ethos of the field and the industry's approach to manage risks through contracts and commitments to a business code).

47. Tenner, supra note 8, at 311-12.

48. Cf. Sylvester et al., supra note 42, at 166 ("Put simply, in this situation of "essential unpredictability,' it is impossible to predict accurately what the future holds. It seems that 'the only way to determine the future is to run it: There are no shortcuts."' (citations omitted)).

49. See Tenner, supra note 8, at 317-18; Hans Fantel, Sound; Portable CD Players Advance, N.Y. Times, May 17, 1987, http://nytimes.com/1987/05/17/arts/sound-portable-cd-players-advance.html.

50. See, e.g., Anderson, supra note 45; Worthington, supra note 45.

51. See Nick Bilton, Disruptions: With a 3-D Printer, Building a Gun with the Push of a Button, N.Y. Times (Oct. 7, 2012, 11:00 AM), http://bits.blogs.nytimes.com/2012/10/07/with-a-3-d-printerbuilding-a-gun-at-home/; Henry Fountain, Tools of Modern Gunmaking: Plastic and a 3-D Printer, N.Y. Times, Jan. 29, 2013, http://www.nytimes.com/2013/01/30/science/surprising-tools-of-moderngunmaking-plastic-and-a-3-d-printer.html.

52. For example, 3D printing requires high heat, which has been a barrier for some types of printing. Yet researchers have just had a breakthrough to allow 3D printing of metal objects such as figures, wires, and tiny letters at room temperature. Amanda Kooser, 3D-Printing with Liquid Metal at Room Temperature, CNET (July 9, 2013, 11:07 AM PDT), http://news.cnet.com/8301-17938_105-57592867-1/ 3d-printing-with-liquid-metal-at-room-temperature/.

53. The AR-15 is the civilian version of the military's M16. See Cyrus Farivar, "Download This Gun”: 3D-Printed Semi-automatic Fires over 600 Rounds, Ars Technica (Mar. 1, 2013, 9:00 AM EST), http://arstechnica.com/tech-policy/2013/03/download-this-gun-3d-printed-semi-automatic-firesover-600-rounds/. 
the lower could handle only a few shots, but about a year later, it could handle 600 shots. ${ }^{54}$ This kind of rapid progress sends shivers up the spines of public officials who want to regulate firearms.

The gun issue highlights how a heavily regulated industry is facing challenges, because many more people can make the regulated things. That shift does not, however, require shackling 3D printing. Other mechanisms are available for regulation. Regulating materials for gun making is one option. If special materials are needed for guns, those materials could be restricted. It also opens the door to legislative mischief and mistakes. Incumbent patentees may lobby Congress to pass statutes that hobble the 3D printing industry. Such efforts could use the fear of guns as a rallying cry for limits on 3D printing that stretch beyond what may be required for those limited issues. The understandable desire to prevent individuals from making untraceable or illegal guns should not cause undue alarm.

Once 3D printers are capable of making guns that work, there will still be ways of controlling that production. One source of regulation involves the material used to make the gun. If only a particular blend of plastic or metal can be shaped into reliable guns, then the solution is to restrict purchases of that material. If guns can be made from a common material, then the answer would be to alert law enforcement authorities when someone buys an unusually large amount of that input, much as some states do with fertilizer because terrorists can make bombs out of that. ${ }^{55}$ Neither of these steps would stop guns from being made in the home, but either one would make it harder to make them (or make many of them). Guns also need bullets, and even if 3D printers can make them, making gunpowder for them is another matter. ${ }^{56}$ Accordingly, policy levers other than legal restrictions on the technology itself can handle the challenges posed by the fact that 3D printers make it easier to produce guns.

The same conclusion follows for product safety concerns. Homemade goods, of course, are not going to be inspected by public officials or carry warning

54. See id.

55. See, e.g., 505 Ill. Comp. Stat. 80/12 (2012) (requiring fertilizer distributors in Illinois to report on certain bulk sales to state regulators and obtain detailed contact information from the purchaser).

56. A leader in 3D printing science has argued that controlling gunpowder is a better option than trying to regulate printing guns:

Perhaps the only way forward, if we choose to try and control this, is to control the gunpowder - the explosives - and not the actual device," Hod Lipson, a Cornell University professor of engineering and an early pioneer of 3-D printing, tells Danger Room. The reason, Lipson says, is that it would be the remaining "controlled substance" in a field that's otherwise uncontrollable, regardless of the shape or size of the firearm that you're using-or printing. It is the "unifying material everybody would need, and it would be a good target for regulation if people choose to regulate it.

Robert Beckhusen, 3-D Printing Pioneer Wants Government to Restrict Gunpowder, Not Printable Guns, Wired (Feb. 19, 2013, 6:30 AM), http://www.wired.com/dangerroom/2013/02/gunpowderregulation/ (emphasis added). 
labels. ${ }^{57}$ Their reliability can be established only through market performance and branding, combined with product liability for the ones that fail. ${ }^{58}$ And yet this shift to branding shows that $3 \mathrm{D}$ printing challenges the foundations of intellectual property. After all, 3D printing also allows anyone to copy a trademarked good or slap a trademark on a product. Similar difficulties exist for copyright and especially for patent. The real lesson from the possible 3D printing of complicated, regulated goods is that almost anything may soon be made by large numbers of people. The political-economic realities under which intellectual property has worked to date have changed. In other words, what will happen to the intellectual property of things?

\section{Patent, Copyright, and Trademark}

3D printing is on the march, and we therefore need to reexamine what intellectual property protection is supposed to do and how its goals should be met. We turn to core premises about how the system functions to show that those foundations may no longer exist, because the physical barriers to infringement are falling. Although 3D printing brings the problems of digitization to patents for the first time, the technology also extends that issue to copyright and trademark. Copyright applies to three-dimensional items such as sculptures and jewelry. And though trademarks are often displayed labels, they also come in the form of product shapes such as a Coca-Cola bottle or an iPhone. 3D printing's effect on copyright and trade dress will be more modest than for patent, but these fields will not escape disruption.

\section{A. PATENTS: INFORMATION EXCHANGE AND CHANGING ARCHITECTURE}

A central paradox of the patent system is that the disclosure requirement enables infringement, yet infringement isn't rampant. Patent law hinges on an exchange, a "bargain." 59 An inventor who obtains a patent is given exclusive rights to make, use, and sell the invention covered by the patent for twenty years. ${ }^{60}$ But this grant has a counterbalance: the inventor must disclose the data

57. Our assumption is that home production will be relatively small from each household. At some point, though, the production could become so large that it could no longer be fairly characterized as "homemade" and different from a manufacturer that is regulated with product inspections.

58. Settled principles in product liability law on warnings will be forced to bend when it comes to 3D printing. Just because anyone can be a manufacturer or a designer does not mean that they should be required to add a warning to their goods or software the way that a firm would. Such a requirement would, at least as applied to small-scale uses, unreasonably inhibit 3D printing in the home. For a discussion of product liability issues in 3D printing, see Lucas S. Osborn, Regulating Three-Dimensional Printing: The Converging Worlds of Bits and Atoms, 51 SAN DiEgo L. Rev. (forthcoming 2014).

59. See Bonito Boats, Inc. v. Thunder Craft Boats, Inc., 489 U.S. 141, 150-51 (1989) ("The federal patent system thus embodies a carefully crafted bargain for encouraging the creation and disclosure of new, useful, and nonobvious advances in technology and design in return for the exclusive right to practice the invention for a period of years.").

60. See 35 U.S.C. § 154(a) (2012); cf. Dan L. Burk \& Mark A. Lemley, Policy Levers in Patent Law, 89 VA. L. Rev. 1575, 1580 (2003) ("There is virtually unanimous agreement that the purpose of the patent system is to promote innovation by granting exclusive rights to encourage invention.”). 
needed to make the invention so that others "skilled in the art" can make and use it. ${ }^{61}$ In the short- and medium-term, the inventor can exploit the patent as she sees fit. In the long-term, the public has a greater store of information on which to draw. ${ }^{62}$ Thus, "the ultimate goal of the patent system is to bring new designs and technologies into the public domain through disclosure." ${ }^{63}$ Because everyone can see the plans in a patent, one would think that there would be high rates of infringement. Infringement does occur, of course, but this fact does not discourage most patent applicants. ${ }^{64}$

Legal sanctions alone do not explain this result. Scale plays a major role in the balance behind enforcement. In many cases, it is too hard to infringe. Intellectual property is best understood not as thwarting all infringement, but as tamping down massive infringement. Put another way, law is just one force that regulates. ${ }^{65}$ Norms, markets, code, and physical architecture regulate as well, and law takes center stage only when the others are insufficient. ${ }^{66}$ Until the printing press came along, for instance, the difficulty and cost in copying books meant that legal protections for an author's interest in her work were beside the point; "nature itself protected that interest. ${ }^{" 67}$ A comparable physical shield was still largely intact for music until the 1990s, when digitization and a key norm-once someone bought a copyrighted item, she could do what she wanted with it—breached that shield. ${ }^{68}$

If technology makes infringement easy, industry incumbents often seek greater protection from the law. They lobby for congressional action to protect their businesses and send their lawyers into court to sue alleged infringers under any possible theory. In both cases, the argument is that the law must rush in, because norms, markets, code, and architecture are no longer enough. Without more

61. 35 U.S.C. $\S \S 111(\mathrm{a})(2)(\mathrm{A}), 112$ (2012).

62. See, e.g., Rebecca S. Eisenberg, Patents and the Progress of Science: Exclusive Rights and Experimental Use, 56 U. Chr. L. Rev. 1017, 1021-22 (1989).

63. Bonito Boats, 489 U.S. at 151.

64. Cf. id. ("The attractiveness of such a bargain, and its effectiveness in inducing creative effort and disclosure of the results of that effort, depend almost entirely on a backdrop of free competition in the exploitation of unpatented designs and innovations. The novelty and nonobviousness requirements of patentability embody a congressional understanding, implicit in the Patent Clause itself, that free exploitation of ideas will be the rule, to which the protection of a federal patent is the exception.").

65. See, e.g., Shubha Ghosh, Decoding and Recoding Natural Monopoly, Deregulation, and Intellectual Property, 2008 U. ILl. L. Rev. 1125; Shubha Ghosh, Patents and the Regulatory State: Rethinking the Patent Bargain Metaphor After Eldred, 19 Berkeley Tech. L.J. 1315 (2004); Mark A. Lemley, Taking the Regulatory Nature of IP Seriously, 92 TEx. L. Rev. 68 (2014); Mark A. Lemley, The Regulatory Turn in IP, 36 Harv. J.L. \& Pub. Pol'y 109 (2013); Ted Sichelman, Purging Patent Law of “Private Law" Remedies, 92 Tex. L. ReV. 517 (2014).

66. $C f$. Ian Ayres \& John Braithwaite, Responsive Regulation: Transcending the Deregulation DeватE 51-53 (1992) (arguing that regulation is not an all-or-nothing matter but rather should be a pyramid of enforcement with self-regulation at the base and command and control with sanction power at the top); Gary E. Marchant, Douglas J. Sylvester \& Kenneth W. Abbott, Risk Management Principles for Nanotechnology, 2 NANOETHICS 43, 51-53 (2008) (adapting regulatory pyramid model to nanotechnology to account for dynamic industry where problems and benefits are not well understood).

67. See Lawrence Lessig, Code: Version 2.0, at 172 (2006).

68. See id. at $172-73$. 
legal protection, they say, some creations or inventions will not occur. Such claims drove many recent changes in copyright policy, including the mandate of digital rights management (DRM) systems. Nonetheless, the litigation and legislative changes failed to protect the old business models for music and books. ${ }^{69}$

3D printing will foster outcomes for many patent industries that are similar to what we see in copyright. The temptation to lobby for legal limits on 3D printing technology will be strong, but firms would be better off embracing this change in production to cultivate new markets instead of trying to win Pyrrhic victories in Congress and the courts. The music and book examples are instructive. Once iTunes launched and Amazon offered a large eBook platform, digital sales for music and books surged. Lower prices for single items, safe files rather than corrupted or malware-infested ones, easy access, and playability opened new markets for digital content. Similar factors should benefit patentees who embrace 3D printing. The charm of home scanning and printing may wear off for a range of reasons. Even a good scan can have errors. One may rely on downloaded files, but an independent design poses security and quality issues.

Materials are another problem. A toy sold in a store is tested to make sure that its material and dyes are safe, its buttons and small pieces remain attached, and so on. These sorts of guarantees do not exist for homemade goods, which gives strong brands a chance to compete. Accordingly, incumbent patent holders have an intellectual property backstop-trademark - to protect them. Before looking at the way patent law and trademark law will interact with the advent of 3D printing, we examine some copyright issues raised by $3 \mathrm{D}$ printing. There is no need to repeat the mistakes of the copyright industry to reach a new patent equilibrium. But given copyright's shadow over digitization debates, it helps to see where 3D printing will further digitization's affect on copyright-reliant industry and where the technolgy will present new challenges to copyright doctrine.

\section{B. COPYRIGHT ORIGINALITY AND MERGER}

When the focus turns to copyright, the impact of 3D printing will be more limited. ${ }^{70}$ The copyright industry has already gone through its wrenching experience with digitization. 3D printers do, however, expand the scope of copyright infringement to physical art such as sculpture and jewelry. Consider the Oscar statuette. The Academy of Motion Picture Arts and Sciences treasures its statuette and has sued to stop reproductions even when made from choco-

69. See, e.g., Michael A. Carrier, Copyright and Innovation: The Untold Story, 2012 Wis. L. Rev. 891, 928 (discussing how music labels are "struggling with a business model that's falling apart in the modern world" (internal quotation marks omitted)).

70. See, e.g., Edward Lee, Digital Originality, 14 VAnd. J. EnT. \& Tech. L. 919, 920-21 (2012); Rideout, supra note 20, at 161; Haritha Dasari, Note, Assessing Copyright Protection and Infringement Issues Involved with 3D Printing and Scanning, 41 AIPLA Q.J. 279, 282 (2013). We thank Michael Weinberg of Public Knowledge for his contribution in drawing our attention to the copyright issues addressed in this section. 
late. ${ }^{71} 3 \mathrm{D}$ printing will enable almost anyone to print an Oscar, but that does not raise any special legal issues. ${ }^{72}$ However, the quest to copyright CAD files will raise new issues under originality and merger doctrine. ${ }^{73}$

Lawyers know that, for a work to obtain copyright protection, the work must be original, but attempts to copyright 3D printing software will make that a more substantial issue. The Supreme Court's opinion in Feist Publications, Inc. v. Rural Telephone Service Co. said that the constitutional threshold for originality "is extremely low; even a slight amount will suffice" and "[t]he vast majority of works make the grade quite easily, as they possess some creative spark, "no matter how crude, humble or obvious' it might be." ${ }^{, 4}$ As a result, virtually no copyrights other than the white pages at issue in Feist have been invalidated as unoriginal. Students learn Feist in their copyright class but rightly conclude that there is not much practical significance to originality unless someone just copies an existing work or a compilation verbatim.

Current law indicates that digital scans will not meet the originality requirement. The simplest case involves a claim that a CAD file scan of an item that is in the public domain can be copyrighted. That claim will face originality problems under Feist. ${ }^{75}$ There is a solid argument that no originality is involved in that design at all. ${ }^{76} \mathrm{~A} 3 \mathrm{D}$ scan that is not modified cannot be compared to a photograph, which is an original (and copyrightable) work that combines reality

71. See James Bates, I'd Like to Thank My Lawyer, L.A. Times, Aug. 1, 1994, http://articles. latimes.com/1994-08-01/business/fi-22296_1_american-express; see also Acad. of Motion Picture Arts \& Scis. v. Creative House Promotions, Inc., 944 F.2d 1446, 1449 (9th Cir. 1991) (suing defendant for “marketing the 'Star Award,' a gold figure closely resembling the Academy's famous 'Oscar' statuette").

72. One possible exception is that a raft of new homemade objects with aesthetic and functional elements may expose the weakness in the conceptual separability doctrine. See 17 U.S.C. $§ 101$ (2012) (stating that "the design of a useful article... shall be considered a pictorial, graphic, or sculptural work [that can be copyrighted] only if, and only to the extent that, such design incorporates pictorial, graphic, or sculptural features that can be identified separately from, and are capable of existing independently of, the utilitarian aspects of the article"). Courts and commentators have failed to reach a consensus about how to apply conceptual separability, which means that anyone who seeks protection on furniture, lamps, and any other practical items that also have artistic merit often do not know if they can rely on copyright protection or must get a patent. See Galiano v. Harrah's Operating Co., 416 F.3d 411, 416-17 (5th Cir. 2005) (stating that there are at least six different tests that are used to determine if a copyright exists in a "useful article").

73. See Feist Publ'ns, Inc. v. Rural Tel. Serv. Co., 499 U.S. 340, 364 (1991) (holding that a phone directory could not be copyrighted because it was not original); Herbert Rosenthal Jewelry Corp. v. Kalpakian, 446 F.2d 738, 742 (9th Cir. 1971) (rejecting a copyright on a decorative pin shaped like a bee because the idea and expression of the jewelry were merged). At present, few software patents cover files for 3D printing because the researchers and enthusiasts in this area are committed to an open-source model. Not many CAD files for specific items should be eligible for patents, however, because most of them will be obvious in relation to prior art. See 35 U.S.C. § 103 (2012).

74. Feist, 499 U.S. at 345.

75. If someone scans an item that is copyrighted, then the resulting CAD file will be a derivative work under the control of the copyright holder. See 17 U.S.C. $§ 101$ (2012). The scan could be a fair use of the copyright, see id. $\S 107$, but that analysis presents questions that we will not address in this Article.

76. See Dasari, supra note 70 , at 300. 
with the expression of the photographer. A person who uses a scanner to get an exact copy of an object, by contrast, contributes nothing to the result. For example, in Meshwerks, Inc. v. Toyota Motor Sales U.S.A., Inc., Toyota hired a company, Meshwerks, to take three-dimensional objects-vehicles-and turn them into two-dimensional representations for advertising. ${ }^{77}$ Meshwerks' efforts were essentially what happens with a 3D scanner today:

Meshwerks took copious measurements of Toyota's vehicles by covering each car, truck, and van with a grid of tape and running an articulated arm tethered to a computer over the vehicle to measure all points of intersection in the grid. Based on these measurements, modeling software then generated a digital image resembling a wire-frame model. In other words, the vehicles' data points (measurements) were mapped onto a computerized grid and the modeling software connected the dots to create a "wire frame" of each vehicle. ${ }^{78}$

Meshwerks gave Toyota the file but objected when Toyota used it for more than one advertisement. ${ }^{79}$ In response to Meshwerks' copyright claim, the Court of Appeals of the Tenth Circuit held that despite "80 to 100 hours of effort," 80 the creations were "not so much independent creations as (very good) copies of Toyota's vehicles." 81 Meshwerks' work did not meet the originality requirement, because "Meshwerks' models depict[ed] nothing more than unadorned Toyota vehicles-the car as car." 82 Thus a scan of a three-dimensional object that renders, or intends to render, the object as is should not be able to receive copyright protection. ${ }^{83}$ But as the court cautioned, digital modeling can "create copyrightable expressions." ${ }^{4}$ Indeed, in Osment Models, Inc. v. Mike's Train House, Inc., a case involving railroad models, a district court held that taking building designs and engaging in "selective compression" to maintain the look of the buildings as it related to a model train layout, as well as changing some visual aspects of the buildings, was sufficient to raise a question of fact about whether the plaintiff's design was copyrightable. ${ }^{85}$ Thus if a scan of a public domain object is modified in some way, the result would satisfy Feist unless the change was trivial. ${ }^{86}$

There is also a merger issue between a CAD file that is designed to make

77. 528 F.3d 1258, 1260 (10th Cir. 2008).

78. Id.

79. Id. at 1261 .

80. Id.

81. Id. at 1264 .

82. Id. at 1265 .

83. See id. at 1268-69 (intent to create an exact copy, such as for a catalog, indicates a lack of originality).

84. Id. at 1269 .

85. No. 2:09-CV-04189-NKL, 2010 WL 5423740, at*6-7 (W.D. Mo. Dec. 27, 2010).

86. See id.; $c f$. L. Batlin \& Son, Inc. v. Snyder, 536 F.2d 486, 492 (2d Cir. 1976) (en banc) (holding that a plastic "Uncle Sam" bank was not an original work because it was otherwise virtually identical to the classic cast iron "Uncle Sam" bank). 
something that is not already copyrighted and the resulting product. Merger is another doctrine that gets a respectful nod in the classroom but is ignored in the real world. The leading case on merger-Herbert Rosenthal Jewelry Corp. $v$. Kalpakian-explained that merger occurs when an idea and its expression are inseparable, and in that case "copying the 'expression' will not be barred, since protecting the 'expression' in such circumstances would confer a monopoly of the 'idea' upon the copyright owner free of the conditions and limitations imposed by ... patent law." ${ }^{87}$ Kalpakian rejected a copyright claim in a jeweled bee pin in large part, because the claim was broad and would "prevent others from engaging in the business of manufacturing and selling jeweled bees." ${ }^{\prime 88}$ Virtually no other copyrights, however, have been invalidated based on a merger analysis. Nevertheless, jeweled bee pins are exactly the type of item that $3 \mathrm{D}$ printers can make, which means merger will be reexamined.

A CAD file may give the merger doctrine more relevance than it has had to date. Consider software that is written to make a statue that looks like one of the giant heads (or moais) from Easter Island. The idea and the expression there could be described as identical — a statue that looks like a giant Easter Island head. The software can only do one thing. Most other software, by contrast, can do multiple things or be described as an expression of some idea (for example, a spreadsheet). The moai program does not present a merger problem if the CAD file is classified at a higher level of generality (making art from indigenous cultures), but it is not clear why the software should be viewed in that way. The design file could also be seen as the specific iteration of a specific trail. Part of the problem may be trying to force visual arts into standards developed for written works. Professor Michael Murray's study of the area argues that merger and the related idea/expression distinction are not evenly applied to visual works, and there is a shift to a "total look and feel" standard instead. ${ }^{89}$ Merger logic may be inapplicable to visual works, because "[v]isual works are a classic example of a situation where ideas can be depicted visually in innumerable ways which should preclude application of the merger doctrine." 90

The vehicle and building examples show the difficulty in deciding how to

87. 446 F.2d 738,742 (9th Cir. 1971).

88. Id. at 740 .

89. See generally Michael D. Murray, Copyright, Originality, and the End of the Scènes à Faire and Merger Doctrines for Visual Works, 58 BAYLoR L. Rev. 779 (2006). Murray discusses cases addressing toys and other three-dimensional renderings but focuses on paintings and photographs to support his critique that there are many ways to render a visual art, and thus the merger doctrine makes little sense for such works:

[A]uthors of visual works on the whole do not copy a stock image in the way that literary works adopt and express a stock scene or situation. There is no set of images that must be copied in order to depict the idea of the image. In the absence of proof that plaintiff did in fact copy a preexisting stock image or "required" image, the merger and scènes à faire doctrines should not apply to visual media.

Id. at 858 .

90. Id. 
evaluate this copyright problem. The software in those cases rendered only the items at issue. In one case, the exact copy was not copyrightable, because it was deemed to lack originality. It could just as easily have been deemed to be that the idea and expression merged: the exact way one presents the Toyota vehicles in the case. In the building case, there are perhaps many ways to render buildings but not the exact buildings at issue given that scaling the buildings to a smaller size and to fit the context of the model town mattered, and consumers want representations "that are as close to reality as possible." "11 Yet unlike the court in Meshwerks, where the original vehicles were also scaled for size and changes were made to allow for the three-dimensional representation of the vehicles, the court noted in Osment that there might be copyrightability for the files in that case. ${ }^{92}$ These examples reveal that merger, like the difference between ideas and expression in copyright, lacks any coherent yardstick. ${ }^{93}$

As more people use scanning technology, copyright doctrine will face unsatisfactory options. It could find that all scans are merger. That would allow for more sharing and reduce rights clearance problems endemic to digital copyright. Yet, excluding design files like those at issue in Osment seems to ignore the originality requirement's low threshold, and a conclusion that merger applies would exclude many design files from copyright protection. Furthermore, the reluctance of courts to find merger in every other area of copyright should raise some doubt about the wisdom of applying the doctrine aggressively here. ${ }^{94}$ These problems arise because 3D printing and the increased ability of individuals to engage in design practices further reveals how digization alters assumptions and seemingly stable analyses in copyright law.

\section{TRADE DRESS AND BRANDING}

The final type of intellectual property that is ripe for disruption by 3D printing is trade dress, which is the physical manifestation of a mark. Trademarks are often words such as Apple or Exxon, but the Lanham Act defines a trademark to "include[] any word, name, symbol, or device, or any combination thereof." ${ }^{95}$ As the Supreme Court has said, "almost anything at all that is

91. Osment Models, Inc. v. Mike's Train House, Inc., No. 2:09-CV-04189-NKL, 2010 WL 5423740, at $* 2$ (W.D. Mo. Dec. 27, 2010).

92. Id. at $* 7$.

93. Cf. Nichols v. Universal Pictures Corp., 45 F.2d 119, 121 (2d Cir. 1930) (Hand, J.) ("Nobody has ever been able to fix that boundary, and nobody ever can.").

94. To the extent that 3D printing software cannot be patented or copyrighted, firms will probably seek some form of digital rights management to prevent their "official" 3D files from being copied. For instance, files could be written so that they only work on certain kinds of printers or require some kind of security code to access. Nathan Myhrvold of Intellectual Ventures, sometimes known as a "patenttroll" firm, has acquired a patent, "Manufacturing control system," aimed at preventing unauthorized printing that has been called "DRM for 3-D printers." See Antonio Regalado, Nathan Myhrvold's Cunning Plan to Prevent 3-D Printer Piracy, MIT Technology Review (Oct. 11, 2012), http://www. technologyreview.com/view/429566/nathan-myhrvolds-cunning-plan-to-prevent-3-d-printer-piracy/.

95. 15 U.S.C. $\S 1127$ (2012). 
capable of carrying meaning" may be a trademark; the Lanham Act is not "restrictive." " So long as the claimed trade dress is distinctive-capable of identifying source-and nonfunctional, one may obtain trademark protection. Thus, trade dress protection has been afforded to the Coke bottle, spray bottles, silverware, and more. Indeed, many firms make substantial investments in product configurations that become recognized by consumers and create a competitive advantage. ${ }^{97}$ The recent Apple and Samsung fight highlights the desire to use design for such an advantage. ${ }^{98}$ One may decry the fight over home buttons, rounded corners, and tapered edges, but the question of protection for design will persist.

With 3D printing, people will be able to make product shapes that look like established trade dress. This practice raises two problems. First, assuming that someone has protection for their trade dress, 3D printing could lead to more trade dress infringement, though in trademark parlance the better description is that there will be more unauthorized third-party users of those marks. ${ }^{99}$ Consequently, product configurations without word marks or corresponding logos should become less valuable. Second, homemade trade dress may require a change in the protection given to that intellectual property. The possibility of widespread trade dress copying affects both pre- and post-registration analysis.

The post-registration analysis is simpler and less startling. Post-sale confusion doctrine holds that infringing trade dress can injure a mark owner even if purchasers of the infringing product are not confused. ${ }^{100}$ How does this work? Many courts say that a third party could see the faux trade dress and be

96. Qualitex Co. v. Jacobson Prods. Co., 514 U.S. 159, 162 (1995).

97. See Deven R. Desai, From Trademarks to Brands, 64 Fla. L. Rev. 981, 1021-25 (2012).

98. See Lea Shaver, Illuminating Innovation: From Patent Racing to Patent War, 69 WASH. \& LEE L. Rev. 1891, 1939-40 (2012).

99. Although successful trade dress dilution claims are rare, one might imagine Coca-Cola or other holders of famous trade dress bringing such claims against someone using a 3D printer to print the trade dress. Dilution by blurring requires that the copied mark's similarity to the famous mark "impairs the distinctiveness of the famous mark." 15 U.S.C. $\$ 1125$ (c) (2012). As with direct copying in copyright, 3D printing does not alter the legal analysis of whether infringement occurs. 3D printing does, however, provide another example of how 3D printing disrupts intellectual property law. Similar to the requirements for registration of a mark that must have secondary meaning, dilution law looks to "[t]he extent to which the owner of the famous mark is engaging in substantially exclusive use of the mark." Id. Even if one accepts dilution as necessary to protect producer interests, 3D printing shows that applying the doctrine to trade dress may be futile. A home user may print Coke bottles and gain the psychological pleasure of drinking from the bottle. Coke will not be able to stop that practice. The idea of substantial exclusivity is undermined if thousands or millions of home users print the bottles. That idea may have to be refocused and anchored on use in commerce. As in other industries such as toys, Coke may choose to sell the plans and materials for the bottle as a way to capitalize on the desire for its bottle.

100. See, e.g., Connie Davis Powell, We All Know It's a Knock-Off! Re-evaluating the Need for the Post-Sale Confusion Doctrine in Trademark Law, 14 N.C. J.L. \& TeCH. 1 (2012) (criticizing post-sale confusion). Counterfeiting is related to post-sale confusion, but in that case, the name, packaging, and configuration are all copied. 
confused in a way that was harmful to the mark owner. ${ }^{101}$ The harm in these cases is not, however, confusion for the purchaser of the good. Instead courts have helped mark holders protect the "prestige" of a mark. ${ }^{102}$ In other words, courts are protecting against someone's ability to make a copy and sell it to someone who knows that the good is a copy, because that copying may reduce the artificial scarcity of the good and its ability to be a status symbol. ${ }^{103}$ This theory is rather tenuous, in that it assumes people make judgments about a brand based on used goods owned by other people without asking what the source was. Even if one accepts that some make such assumptions, in a world of 3D printers, whatever ground may have supported post-sale confusion is eroded. There will be less, or perhaps no, reason for consumers to think that any popular trade dress observed outside of a store was made by the brand owner. An equally valid conclusion is that products that look similar and are being used by someone else were, in fact, homemade.

This point reveals a larger insight about trade dress protection. Product design trade dress - such as for a spray bottle or cellular phone-can have trademark protection, but only after a showing of acquired or secondary meaning. ${ }^{104}$ The secondary meaning standard accepts as prima facie evidence "proof of substantially exclusive and continuous use thereof as a mark by the applicant in commerce for the five years before the date on which the claim of distinctiveness is made." ${ }^{\prime 05}$ With the advent of $3 \mathrm{D}$ printing, substantially exclusive use may be quite difficult to show, or at least the idea has to be rethought. Thus, 3D printing highlights issues in the so-called use debate. ${ }^{106}$ Imagine that Monster Energy drinks has just released a new bottle for its new drink. Then a million people print the bottle to use with their SodaStream. If home printing is a use in commerce that counts for trademark analysis, then substantially exclusive use to acquire secondary meaning may be almost impossible. That position would also mean that home printing of trade dress for personal use could infringe trade-

101. See, e.g., Ferrari S.P.A. v. Roberts, 944 F.2d 1235, 1243 (6th Cir. 1991); Lois Sportswear, U.S.A., Inc. v. Levi Strauss \& Co., 799 F.2d 867, 868 (2d Cir. 1986).

102. See Mastercrafters Clock \& Radio Co. v. Vacheron \& Constantin-Le Coultre Watches, Inc., 221 F.2d 464, 466 (2d Cir. 1955).

103. See Desai, supra note 97, at 1026.

104. Distinctiveness and trade dress protection is a bizarre area of trademark law. Trade dress must be distinctive to receive trademark protection, but there are two types of distinctiveness: inherent and acquired. If a mark is inherently distinctive, registration and protection is easier to obtain. The Supreme Court has held that trade dress such as a restaurant design or product packaging can be inherently distinctive. See Two Pesos, Inc. v. Taco Cabana, Inc., 505 U.S. 763, 770 (1992). Unregistered product design, however, must have secondary meaning to obtain trademark protection. See Wal-Mart Stores, Inc. v. Samara Bros., Inc., 529 U.S. 205, 216 (2000).

105. 15 U.S.C. $§ 1052(\mathrm{f})(2012)$.

106. See Stacey L. Dogan \& Mark A. Lemley, Grounding Trademark Law Through Trademark Use, 92 Iowa L. Rev. 1669, 1670 (2007) (arguing the use requirement in trademark law should limit trademark holder claims on new issues unless Congress makes specific authorization). But see Graeme B. Dinwoodie \& Mark D. Janis, Confusion over Use: Contextualism in Trademark Law, 92 IowA L. Rev. 1597,1603 (2007) (rejecting use theory and arguing that "[1]imiting liability to trademark use, as that term is understood by its proponents, will thus result in insufficient marketplace regulation"). 
mark rights. The position is circular. The mark holder can't stop the home use but has to do so to maintain rights that arguably should not be granted. 3D printing therefore demonstrates that use in commerce may be an important limiting factor for trademark rights. Home printing of trade dress or trademarks may be precisely the sort of practice that does not cause confusion and should not be deemed infringement, yet under current law could be seen as infringing.

In that sense, 3D printing reveals the sumptuary nature of intellectual property. ${ }^{107}$ Many may want to use a 3D printer to create or have the logo or design, not the original goods. Yet trademark law prevents such activities even when no one is confused. For example, Barton Beebe has argued that the anonymous source doctrine, which holds that there must be a single source for a good but that ordinary consumers need not know precisely where or how a good is made, allows for the creation of "hypermarks"- marks that have value for their sign and prestige value rather than signs of a good's source. ${ }^{108}$

Other doctrines such as goodwill, licensing, and merchandising allow firms to establish a certain quality and then alter it, but few would know about the change or have recourse. ${ }^{109}$ The irony is that as more places of manufacture arise, consumers may demand greater assurances about goods. ${ }^{110}$ Assumptions underlying anonymous source, goodwill, licensing, and merchandising doctrines in trademark law may be less accurate or untenable in the modern marketplace. ${ }^{111}$ As the ability to mimic trademarks and trade dress spreads, 3D printing reverses the world where consumers are led to believe that almost all uses of a mark are licensed. That belief has led to a cycle of expanding trademark and other intellectual property rights, a type of "rights accretion" fed by producer behaviors and demands. ${ }^{112}$

Nevertheless, the decline in patent protection caused by $3 \mathrm{D}$ printing means that brands will become more important even as one branding technique-trade dress-becomes less important. When firms are selling essentially the same thing or something easily copied, branding is crucial for differentiating products and allows established companies to use other services they offer as leverage with consumers. ${ }^{113}$ For example, price dispersion-where prices stay above marginal cost in an otherwise competitive market-should mean that after-

107. See Barton Beebe, Intellectual Property Law and the Sumptuary Code, 123 Harv. L. Rev. 809, 815 (2010).

108. See Barton Beebe, The Semiotic Analysis of Trademark Law, 51 UCLA L. Rev. 621, 669 (2004).

109. See, e.g., Desai, supra note 97, at 1011-19 (detailing how the shift to expansive goodwill and permissive merchandising uncoupled quality control from trademark law); see also J. Shahar Dillbary, Getting the Word Out: The Informational Function of Trademarks, 41 ARIZ. ST. L.J. 991, 1029 (2009) (noting difficulty in detecting quality shifts).

110. See generally Desai, supra note 97.

111. See, e.g., id. at 1011.

112. See James Gibson, Risk Aversion and Rights Accretion in Intellectual Property Law, 116 YALE L.J. 882, 907-08 (2007).

113. See Desai, supra note 97 , at 1023-24. 
market auto parts, generic drugs, and house-brand cleaning supplies should bring prices down to cost. ${ }^{114}$ Incumbent brands that began with patent protection - for example, Tylenol—ought not be able to maintain their price premium. Yet they do. Generic makers and companies that design around a patent to offer compatible goods face a different competitive problem. They must maintain quality and build their brands to compete with incumbent patent holders even after the patent has expired.

With 3D printing, all producers may have to take a stronger stand about ingredients and safety as they compete over selling essentially the same goods. Firms that back up their goods and enforce quality control should have an advantage over those who do not as consumers seek trusted goods and services. ${ }^{115}$ Many people will want to buy from a brand that is not so anonymous, guarantees safe files or materials, and offers a customer service desk, rather than rely on software from an unknown author or on plastic from a local shop. Companies can also offer 3D files and accessories as a bonus for purchasing expensive items based on patents that cannot be replicated at home (for example, if you buy a smartphone, you get a free file and plastic to make your own case or headphones). As a result, 3D printing presents an opportunity to enhance brand power through safety, quality, and ongoing engagement with the company.

In sum, optimal innovation outcomes are not driven solely by legal rules. ${ }^{116}$ They depend instead on a complex interplay of norms, physical architecture, and business necessity. Nonetheless, the rise of 3D printing calls for some modifications in IP law, and we now turn to how Congress should respond.

\section{Congressional Regulation}

There is no reason for patent and trademark law to repeat the mistakes of copyright, but there is every reason to think that these mistakes will be repeated. This Part asks what Congress should do to assist the growth of 3D printing while giving households and firms clear guidance about their legal obligations. First, some infringement exemption for personal 3D printing should be created that would not facilitate large-scale commercial manufacturing. ${ }^{117}$ Second, a

114. See Deven R. Desai \& Spencer Waller, Brands, Competition, and the Law, 2010 BYU L. Rev. $1425,1442$.

115. In a way, this shift connects to early functions of trademarks. Trademarks trace their origin, in part, to government-required liability marks. See generally Frank I. Schechter, The Historical Foundations of the LaW Relating to Trade-Marks (1925). The maker of a good had to affix a mark so that the government could hold the producer responsible if an arrow, sail, brick, or other good was not up to standards. See id. at 47; Edward S. Rogers, Some Historical Matter Concerning Trade-Marks, 9 Мich. L. Rev. 29, 29 (1910).

116. See Saxenian, supra note 41 , at $423-24$.

117. Cf. Audio Home Recording Act of 1992, Pub. L. No. 102-563, § 1008, 106 Stat. 4237, 4244 (permitting individuals to make noncommercial digital music recordings at home free from copyright infringement liability). 
Digital Millennium Patent and Trademark Act (DMPA) should be enacted that would impose notice and takedown rules on the sites that host $3 \mathrm{D}$ printing software. With these reforms, Congress would strike a sound balance between patent rights and this disruptive technology.

\section{A. THE 3D ECOSYSTEM}

3D printers cannot infringe on their own. There are several parts to the $3 \mathrm{D}$ printer environment, as shown in this diagram:

\section{D Printer Vulnerability Points}

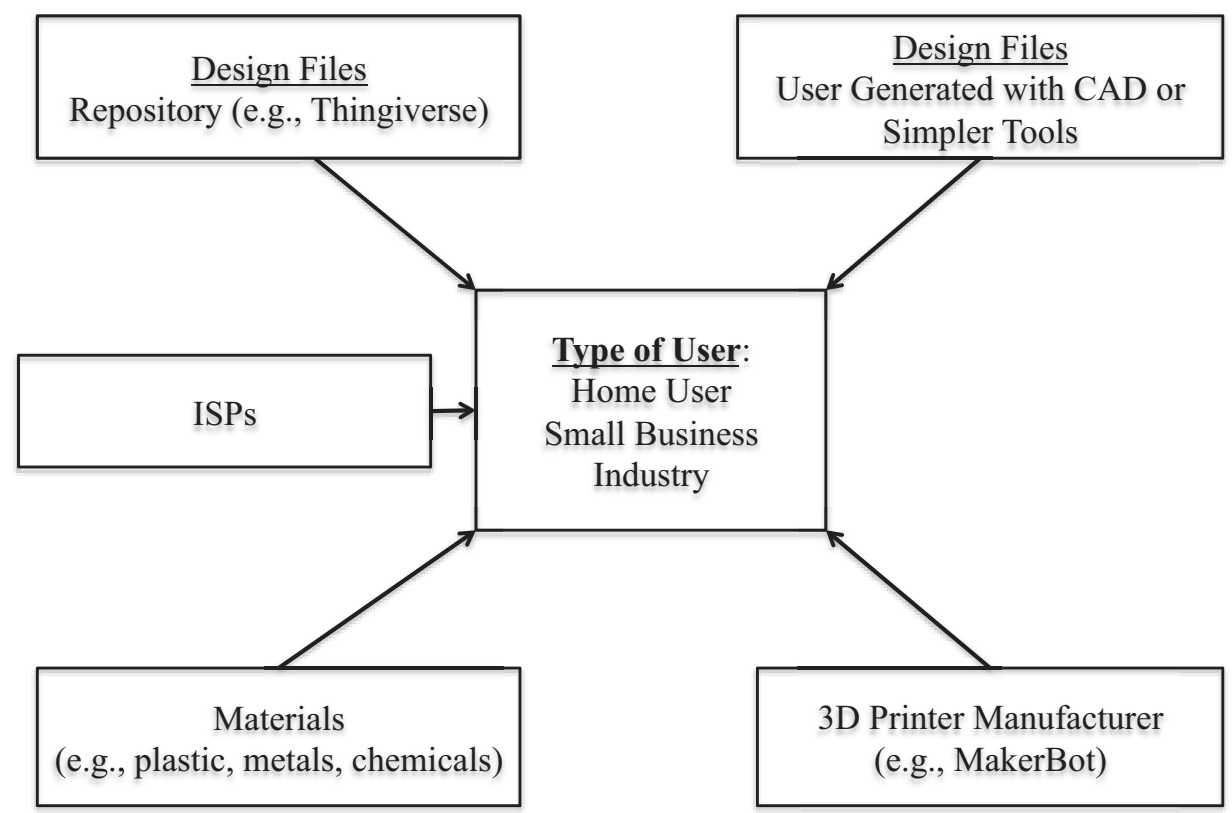

Of course, the end user will need a printer, which will come from some manufacturer until 3D devices can self-replicate. ${ }^{118}$ Patentees could try to sue these manufacturers (or producers of other useful hardware such as scanners) for contributory infringement, but those suits are unlikely to succeed, because the hardware can be used for many noninfringing purposes. ${ }^{119}$ Next comes the

118. See, e.g., Ben Rooney, The 3D Printer that Prints Itself, Wall St. J. (June 10, 2011, 1:20 PM GMT), http://blogs.wsj.com/tech-europe/2011/06/10/the-3d-printer-that-prints-itself/.

119. 35 U.S.C. $§ 271$ (c) (2012) provides:

Whoever offers to sell or sells within the United States or imports into the United States a component of a patented machine, manufacture, combination or composition, or a material or apparatus for use in practicing a patented process, constituting a material part of the invention, 
raw material (for example, plastic or metal), which again is suited for both infringing and noninfringing articles. ${ }^{120}$ Finally, there is the software, which could be written by the user, acquired from a friend, or downloaded from a site that hosts CAD files. ${ }^{121}$ Those sites could be vulnerable to litigation for hosting infringing software.

One option that Congress should avoid is limiting the technology associated with 3D printers. Patentees and regulators may seek to constrict hardware capabilities so that they cannot print certain items or print them well. They could also lobby for some form of digital rights management to set up similar controls. At this stage, however, mandating the operational details of 3D printers would be a clumsy way of dealing with the challenges posed by this new type of digitization. In addition, it could reinvent a rejected wheel. Early CAD systems had to connect to "another computer configured as a license server [that had to] approve use of the software, or [use] a dreaded hardware 'dongle' installed on the computer [to] authorize use of the software." 122 Slight deviations yielded error messages and prevented use of the machine. ${ }^{123}$ It is precisely this sort of limit that the 3D printing community rejected in adopting open-source architecture and software. ${ }^{124}$

Furthermore, research is moving so fast in this field that any direct governmental controls would be quickly rendered obsolete and may do significant harm. It is possible that there will be a technological solution to the infringement problems that we discuss, but if so, that is something that should emerge from the marketplace. For example, streaming audio and video content can be understood as a response to file sharing and some of the legal protections for online service providers. A possible response for some patent holders may be to

knowing the same to be especially made or especially adapted for use in an infringement of such patent, and not a staple article or commodity of commerce suitable for substantial noninfringing use, shall be liable as a contributory infringer.

Proving that $3 \mathrm{D}$ printers are not "suitable for substantial noninfringing use" will be impossible. 35 U.S.C. $\S 271$ (c) (2012). After all, they can make objects in the public domain or things that do not qualify for a patent due to obviousness. The likelihood that a 3D printer will be used for a noninfringing purpose is probably greater than for the VCR, which was held to be capable of substantial noninfringing use in the copyright context. See Sony Corp. of Am. v. Universal City Studios, Inc., 464 U.S. 417, 456 (1984).

120. Some of these raw materials could be patented if they are adapted in a special way for a $3 \mathrm{D}$ printer, and that kind of patent would be much more difficult to circumvent than ones for finished products or designs.

121. It is possible that a provider of $3 \mathrm{D}$ printing hardware, raw materials, or software could be liable for the inducement of infringement. See 35 U.S.C. $\$ 271$ (b) (2012); see also Akamai Techs., Inc. v. Limelight Networks, Inc., 692 F.3d 1301, 1336 (Fed. Cir. 2012) (en banc) (addressing inducement when multiple parties combine to infringe a patent). Only foolish or brazen firms would fall into this trap, though, since the liability for active inducement is relatively clear and there are plenty of legitimate ways to market 3D printing. As a result, lawsuits under $\S 271$ (b) are not going to make a dent in infringement by $3 \mathrm{D}$ printers.

122. GERSHENFELD, supra note 31 , at 45 .

123. Id.

124. See supra note 37. 
make 3D printer files available via a networked printer. ${ }^{125}$ That way one might rent the file for a number of prints but the file would be less easily copied and shared. Such a solution is less likely to emerge without giving home users some protection from potential infringement claims.

\section{B. LIFTING THE THREAT OF PERSONAL INFRINGEMENT LIABILITY}

An obstacle to the growth of $3 \mathrm{D}$ printing that Congress should consider addressing is that individuals who engage in that activity are strictly liable if they infringe a patent. ${ }^{126}$ Although the chances that any given person will be sued for direct infringement are low, there could be a chilling effect on those who are risk-averse or think that it is immoral to engage in illegal conduct even when they will never be caught. Sophisticated firms fail to find patents that conflict with their work, so there is little hope that the average person or small business can navigate that minefield and be sure that they are not infringing. ${ }^{127}$ Even if potential infringement liability by end users does not retard the growth of the technology, it is unclear why personal 3D printing should be unlawful, especially given the futility of enforcement. ${ }^{128}$ A norm of benign neglect for 3D infringement is fine, but it is not the same as declaring the conduct legal or saying that there can be no remedy for the patentee. A handful of people, after all, will be sued by patentees and required to pay damages, and there is something deeply unfair about an enforcement scheme (as occurred with the sharing of copyrighted music) that imposes hefty sanctions on a few while letting almost everyone do what they want. Congress did not exempt personal production from patent infringement, because few could make patented devices at home. Now that this physical limit is disappearing, maintaining a liability standard created for another age does not make sense.

Exempting personal 3D printing from patent infringement without undermining other aspects of the regulatory scheme will not be easy. It would not be a good idea for Congress to create a fair use exception for all patents or make

125. Granted, someone can make an object from a networked printer, scan it, and then share that file outside of the network. In practice, this may mean that networked printers will only be feasible for more complex products that are not susceptible to scanning.

126. There is no fair use exception in patent law as there is in copyright. See generally Maureen A. O'Rourke, Toward a Doctrine of Fair Use in Patent Law, 100 Colum. L. Rev. 1177 (2000) (discussing the considerations involved in the lack of a fair use exception in patent law). While there is an exception for "experimental use," this immunity is read narrowly and would probably not apply to the personal manufacture and use of most goods from a 3D printer. See, e.g., Madey v. Duke Univ., 307 F.3d 1351, 1361 (Fed. Cir. 2002) (interpreting experimental use as a "very narrow and strictly limited" defense). There is a solid argument that experimental use should be read more broadly to include at least some 3D printing in homes or businesses, but this is probably not a path that the Federal Circuit will explore.

127. $3 \mathrm{D}$ infringement that is knowing and deliberate is different, though that may go to damages rather than liability.

128. Of course, the inability of patentees to stop individuals from infringing patents on 3D printers could lead Congress to take the opposite approach and increase the penalty for that conduct. A similar crackdown on illegal downloads of copyrighted music, though, did not accomplish much. 
infringement an intentional tort, as those changes would sweep too far. Targeting $3 \mathrm{D}$ printing itself is a possibility, but in that case the legislation would have to distinguish between personal and commercial activity, as there is no rationale for saying that all 3D printing leading to patent infringement, including what Fortune 500 firms do, should be permitted. Drawing that kind of line with a substantive legal standard, though, will generate years of litigation and may not effectively separate the good from the bad.

One alternative, should Congress opt to give personal 3D printing some immunity, would be to set a relatively high minimum amount-in-controversy for federal jurisdiction over any infringement claims involving this technology. ${ }^{129}$ Congress considered (but never enacted) a related idea during the late nineteenth century in response to a spike in infringement suits brought against farmers. ${ }^{130}$ Denying a remedy to patentees when the injury from unlawful activity is small would not concede that home 3D infringement is valid, but such a rule would ensure that there would be no civil liability and would serve as a de facto fair use exception. Such a jurisdictional threshold would also have the advantage of being a rule, and as such would be clearer and easier for courts to apply. ${ }^{131}$ If Congress is uncertain about what the amount should be or how the amount should be calculated, then the PTO could be delegated the task of formulating guidelines. In some specific instances a sufficient harm could be presumed, but otherwise the burden should rest with the patentee to prove that the jurisdictional minimum is met, which in practice will be difficult. ${ }^{132}$

129. Cf. Pamela Samuelson \& Tara Wheatland, Statutory Damages in Copyright Law: A Remedy in Need of Reform, 51 WM. \& MARY L. Rev. 439, 443 (2009) (arguing that the advent of the average person's day-to-day interaction with copyright law requires rethinking of statutory damage awards, which "are particularly likely to be grossly excessive when compared with actual damages in class action suits, or secondary liability cases such as those against technology developers, where the number of works potentially infringed is likely to be large").

130. See Gerard N. Magliocca, Blackberries and Barnyards: Patent Trolls and the Perils of Innovation, 82 Notre DAME L. Rev. 1809, 1832-33 (2007) (summarizing these proposals).

131. What we have in mind is an amount in the $\$ 3000-\$ 5000$ range, which would provide a rough distinction between innocuous and worrisome activity. Of course, this sort of jurisdictional limit could work only if patentees are not allowed to aggregate claims to reach the necessary amount-incontroversy, either through a class action or via ordinary pleading.

132. There is a good case for extending this framework to copyright. Strict liability for copyright infringement is tempered by a fair use exception, but in practice that does not offer much solace to an individual who might get sued by an intellectual property owner. Thus, there is no meaningful daylight between patents and copyrights with respect to the fairness of creating an exemption for at least some personal production. Trademark infringement presents a more complex problem. If the personal production of trade dress is not considered "use in commerce," see supra text accompanying notes 106-08, then there would be no need to establish a jurisdictional minimum, because there would be no cause of action that could lead to civil liability. When the "use in commerce" prong is satisfied, the question would be whether the higher threshold for proving trademark infringement-it is not a true strict liability tort-provides adequate protection to individuals who print their own trade dress. That issue is subject to debate. See, e.g., Desai, supra note 97, at 999-1005, 1029 (arguing that trademark law ignores the consumer and community dimensions of trademarks); see also Deven R. Desai, Speech, Citizenry, and the Market: A Corporate Public Figure Doctrine, 98 Minn. L. Rev. 455, 458 (2013) (discussing problems with the likelihood of confusion test and free speech); William McGeveran, 


\section{A PATENT AND TRADEMARK DMCA}

Another issue that Congress should address is the potential liability of $3 \mathrm{D}$ printing digital intermediaries. Websites that host files that tell 3D printers how to make patented and trademarked items could be sued for contributory infringement. When similar claims were raised against Napster (for music) and eBay (for counterfeits), courts held that these sites were liable for contributory copyright or trademark infringement if they had specific knowledge that illegal copies were being traded or sold and did not take appropriate action. ${ }^{133}$ One might think, therefore, that a website that serves as a conduit for $3 \mathrm{D}$ printer software should be liable for contributory infringement if it refuses to take down a file after receiving a plausible complaint from a patentee. Indeed, some 3D printing sites, such as Thingiverse and Shapeways, have a notice-and-takedown policy, in part because some of their CAD files cover copyrighted content. ${ }^{134}$

Without a DMCA for patents and trade dress, though, considerable litigation will be required to clarify the rights and responsibilities of patentees and websites. ${ }^{135}$ We think that extending the notice-and-takedown rules of the DMCA is the simplest solution, because these sites are already complying with those rules for files involving copyrights. It would also be odd to have two sets of rules for these clearinghouses, one for copyrights and another for patents and trade dress. As with copyrights, patentees and trade dress owners would bear the burden of identifying infringing material. Although the framework created by the DMCA is still controversial in some quarters, the notice-and-takedown system works reasonably well. ${ }^{136}$ Moreover, the fair use concerns that are at the

Rethinking Trademark Fair Use, 94 Iowa L. Rev. 49, 71 (2008) (explaining how trademark law chills speech and calling for new contours to fair use in trademark law).

133. See Tiffany (NJ) Inc. v. eBay Inc., 600 F.3d 93, 107 (2d Cir. 2010) ("For contributory trademark infringement liability to lie, a service provider must have more than a general knowledge or reason to know that its service is being used to sell counterfeit goods. Some contemporary knowledge of which particular listings are infringing or will infringe in the future is necessary."); A\&M Records, Inc. v. Napster, Inc., 239 F.3d 1004, 1021 (9th Cir. 2001) ("[I]f a computer system operator learns of specific infringing material available on his system and fails to purge such material from the system, the operator knows of and contributes to direct infringement. Conversely, absent any specific information which identifies infringing activity, a computer system operator cannot be liable for contributory infringement merely because the structure of the system allows for the exchange of copyrighted material." (citation omitted)).

134. See 17 U.S.C. § 512(c)(1) (2012); Doherty, supra note 3, at 363. Of course, it is unclear how these companies administer their policies and evaluate infringement claims against legitimate user interests. The concern is that without legislation the private versions of notice and takedown are in fact deferential to intellectual property holder claims without meaningful evaluation given the complexities of evaluating any patent infringement claims in court, let alone in private settings.

135. See Doherty, supra note 3, at 365-68 (explaining how such a statute might work).

136. The give and take between the copyright industries and Silicon Valley indicates that the DMCA, even with its arguable flaws, hit the sort of regulation proper for emerging technologies. For example, Google's YouTube could have tried to rely on the DMCA and deny any responsibility for content on the site. See 17 U.S.C. §512(c)(1) (2012). Yet copyright lawsuits and questions about whether the DMCA was still fair forced a type of self-regulation. YouTube developed Content ID. In that system, copyright holders share digital fingerprints of their work with YouTube. When a user creates a file, it is compared against the fingerprint database. If it appears to be a match, the copyright 
heart of the opposition to the DMCA are completely absent for patents and largely irrelevant for trade dress. ${ }^{137}$

In sum, Congress could assist the dissemination of 3D printing by limiting the infringement liability for personal use in the patent sphere and clarifying the standards that govern digital intermediaries for patents and trade dress.

\section{CONCLUSION}

3D printing is the next step in general-purpose computing. Michelangelo said that he made statues by removing the parts of the stone that hid the sculpture, but 3D printing promises to transform manufacturing by applying the opposite idea. ${ }^{138}$ Activities that were once the province of only a few are now in the hands of many. The patent system has been able to require disclosure of how a process works, because the cost to infringe was high. Now, cost structures that once required an inventor to find a deep-pocketed outside backer are gone. The design, manufacture, and distribution of goods is easier, faster, and less expensive than ever before. These tasks can be done at home, in a start-up, or at a large business. Patent law and industries that rely on patents will have to adapt to this new environment or face potential obsolescence.

Given the disruptive potential of 3D printing and the large swaths of the economy affected by that technology, it will take just one or two industry groups to force a repeat of the mistakes of the copyright wars instead of applying the best lessons from them. Some may wish to follow the copyright industry's strategy of seeking new laws to prosecute anyone who uses this new technology to infringe a patent. Some may demand technological solutions similar to digital-rights-management tactics deployed by the copyright industry. Some may want to attack intermediaries who provide the files for potential infringement. The DRM solution has not worked. Attacking blatant piracy sites is still an option, but demanding that intermediaries such as eBay or YouTube be shut down has been rejected as a solution. Thus the book, music, and film industries world has started to abandon such strategies, embrace digital distribution, and still make healthy profits. ${ }^{139}$

3D printing should be lightly regulated, because it enables precisely the kind

holder is notified and then chooses how to proceed by either issuing a takedown notice under the DMCA, doing nothing, or choosing to place advertisements and/or links to buy the song on the page where the video is watched. See, e.g., Jonathan Bailey, 9 Questions and Answers Regarding YouTube and Content ID, PlagiarismToday (Dec. 23, 2013), http://www.plagiarismtoday.com/2013/12/23/9questions-answers-regarding-youtube-content-id/ (explaining the history of Content ID creation and difficulties in implementing the system).

137. We are not saying that there is no circumstance where trade dress could lead to a fair use or free expression claim, but that is far less likely than in the copyright context.

138. There is no authoritative source for this quote, which may be apocryphal.

139. It is well beyond the scope of this Article to address the fairness of the change in profits. We acknowledge the debate about the change in income to these industries. Profits have probably gone down, but they still exist. The best questions here are what is a reasonable profit and what rent extraction may have been reduced. It is one thing to show that an industry cannot make any profit. It is 
of creation and progress of the useful arts and sciences that intellectual property is supposed to foster. The locus of that good work is shifting, but that does not diminish that progress is occurring often faster and at less cost. The dawn of the Web increased and revealed the scale at which individuals and businesses engaged with, shared, and used copyrighted or trademarked intellectual property. At scale, the old models of enforcement and what constituted infringement had to be rethought. To have had even the chance for the PC and Web industries to experiment, grow, and thrive, the specter of copyright lawsuits or trademark lawsuits had to be mitigated. Trying to stop or dictate the way a 3D printer is used unduly limits the potential of these general-purpose machines and mimics the failed DRM ideas of the copyright industry. The largest threat comes from uncertainty in the law. Revising patent law to have a high minimum amount-incontroversy as a jurisdictional threshold would create a de facto fair use standard for home and experimental 3D printing activities. In addition, a patent DMCA would strike a balance between rights holders and intermediaries. As has happened in the copyright world, such a law has fostered new marketplaces and revenue models that allow for greater sharing, remixing, and selling of intellectual property. Without these changes, 3D printing could be mired in fights over protecting old business models. And mistaken regulation could fall into path-dependent solutions where creators are told to use a 3D printer only for certain purposes. These changes, therefore, balance interests and create the space 3D printing needs to become the foundation for the next wave of general-purpose computing and creation.

another to show that profits realigned. It is still another to explain what is needed to protect film or pharmaceutical making versus music or software. 